\title{
Evidence for an Effect of Insulin on the Peripheral Utilization of Ketone Bodies in Dogs
}

\author{
E. O. Balasse and R. J. Havel \\ From the Cardiovascular Research Institute and Department of Medicine, \\ University of California School of Medicine, San Francisco, California 94122
}

A B S T R A C T The rates of transport and oxidation of acetoacetate have been measured in seven anesthetized, pancreatectomized, ketotic dogs using a constant infusion of acetoacetate- $3-{ }^{14} \mathrm{C}$. Control experiments were performed in 14 normal dogs. In addition to the acetoacetate $-{ }^{14} \mathrm{C}$, the latter were infused at a constant rate with varying amounts of unlabeled acetoacetate so as to obtain a range of ketone transport $(26-65 \mu \mathrm{moles} / \mathrm{min} \cdot \mathrm{kg})$ comparable with that observed in the diabetic dogs (21$41 \mu$ moles $/ \mathrm{min} \cdot \mathrm{kg}$ ). The specific activities of acetoacetate and $\beta$-hydroxybutyrate in blood became equal during the infusion of labeled acetoacetate, indicating that the net transport of acetoacetate represents that of total ketones. In each group, the concentration of ketones was an exponential function of the rate of transport, but for any value below $30 \mu$ moles $/ \mathrm{min} \cdot \mathrm{kg}$, ketone concentration in the diabetic dogs was about 3 times that in normal dogs, indicating an impairment of mechanisms for utilizing ketones in insulin deficient animals. Maximal capacity to utilize ketones in diabetic dogs was slightly more than half that of normal ones. A similar fraction $(32-63 \%)$ of the infused ${ }^{14} \mathrm{C}$ appeared in respiratory $\mathrm{CO}_{2}$ in the two groups and was independent of the rate of transport. In seven of the normal dogs, administration of insulin and glucose increased removal of the infused ketones and increased the fraction of ${ }^{14} \mathrm{C}$ appearing in respiratory $\mathrm{CO}_{2}$. These results demonstrate that utilization of ketones in extrahepatic tissues is influenced by insulin; impaired utilization contributes to diabetic

This work was presented in preliminary form at the fifth annual meeting of the European Association for the Study of Diabetes held in Montpellier, France, September 1969 (1).

Dr. Balasse was a U. S. Public Health Service International Postdoctoral Research Fellow, and his present address is Université Libre de Bruxelles, Belgium.

Received for publication 12 November 1970. ketosis and is probably essential to the production of severe ketoacidosis.

\section{INTRODUCTION}

It is well established that ketone bodies are manufactured primarily in the liver and transported through blood to peripheral tissues where they are readily oxidized. Under certain conditions, ketones produced in liver may account for a considerable fraction of caloric requirements $(2,3)$. The regulation of production of ketones by the liver has been extensively studied both in vivo and in vitro (4-7). In the intact organism, high rates of ketogenesis are observed essentially in situations characterized by high free fatty acid (FFA) levels associated with carbohydrate deprivation as in starvation or diabetes. Little is known about factors controlling the peripheral utilization of ketone bodies. The only well-established data are that ketone utilization is accelerated by increased concentrations of ketones in blood $(8,9)$ and by increase in the metabolic rate such as occurs in muscular exercise (10). A possible role of insulin in the control of ketone utilization has been investigated repeatedly during the last $40 \mathrm{yr}$. Conflicting reports have appeared. Earlier work in several mammalian species indicated that ketone body utilization is not impaired in diabetes (11-16), whereas more recent reports indicate that some impairment may exist in diabetic rats and that it can be corrected by insulin (17-20).

Recent work from this laboratory has shown that hyperketonemia in dogs with diabetic ketosis exceeds that observed in norepinephrine-infused, nondiabetic animals with comparable rates of hepatic ketogenesis (21). This observation has led us to reevaluate the problem of ketone utilization in this species with isotopic techniques which permit measurement of rates of transport and oxidation of ketones. For this purpose, diabetic dogs have been compared with normal animals made ketotic by infusing acetoacetate (AcAc). 


\section{METHODS}

\section{Experimental animals and procedures}

Two groups of male mongrel dogs weighing $13-28 \mathrm{~kg}$ were studied: (a) normal dogs maintained on a diet containing approximately $75 \%$ protein and $25 \%$ fat and fasted for $18 \mathrm{hr}$, and $(b)$ pancreatectomized dogs fasted for $18 \mathrm{hr}$ and deprived of insulin for 48-72 hr to allow the development of variable degrees of ketosis. The animals were depancreatized at least 1 month earlier and maintained on the same diet as that of normal animals but supplemented with crude pancreatin and given NPH insulin subcutaneously once daily to maintain urinary excretion of glucose below $15 \mathrm{~g}$ daily. Animals from both groups were in excellent nutritional condition.

On the day of the experiment, anesthesia was induced with sodium pentobarbital $(25-30 \mathrm{mg} / \mathrm{kg}$ ) and maintained by additional smaller doses to prevent shivering or other muscular activity. The animals were intubated and ventilated artificially with air at a constant rate $(0.17-0.29$ liter/ $\min \cdot \mathrm{kg}$ ). Catheters were introduced into the vena cava through a superficial leg vein for infusion, into a femoral artery through a side branch for blood sampling and into the bladder for urine collection. The diabetic animals were given a constant infusion of trace amounts of AcAc- $3-{ }^{14} \mathrm{C}$ diluted in saline $(0.01-0.02 \mu \mathrm{Ci} / \mathrm{min} \cdot \mathrm{kg})$. The normal animals were infused with a mixture of AcAc- $3-{ }^{14} \mathrm{C}(0.001-0.02$ $\mu \mathrm{Ci} / \mathrm{min} \cdot \mathrm{kg}$ ) and unlabeled AcAc (26.3-77.5 $\mu$ moles $/ \mathrm{min} \cdot$ $\mathrm{kg})$. In both diabetic and normal dogs, infusions were continued for 3-6 hr and were preceded by injection of a priming dose equivalent to 15 times the infusion rate per min. Samples of arterial blood, expired air, and urine were collected at intervals during the course of the experiment.

In a few experiments on normal dogs, blood was also sampled from the femoral vein and the portal vein through appropriate catheters (the portal catheters were implanted through a branch of the splenic vein at laparotomy about 6 days before the experiment [21]). At the end of two experiments on normal dogs infused with AcAc, samples of adipose tissue, skeletal muscle, liver, and kidney were taken for analysis. In one of these experiments ( $\operatorname{dog} 58$ ), the infused tracer was $D(-) \beta$-hydroxybutyrate $\cdot 3-{ }^{14} \mathrm{C}$ rather than AcAc-3- ${ }^{14} \mathrm{C}$. The influence of blood $\mathrm{pH}$ and of administration of insulin on the utilization of ketones were also studied. The experimental protocols are described together with the results.

Production rate of ketones by the liver was measured directly in seven normal, fasted dogs fitted with catheters in an artery, the portal vein, and an hepatic vein (21). Hepatic blood flow was measured using a constant infusion of ${ }^{131} \mathrm{I}$-labeled rose bengal into a peripheral vein $(22)$. Calculations of production rates of ketones were made assuming that $80 \%$ of the hepatic blood flow was derived from the portal vein (21).

\section{Analyses}

Blood samples were collected with glass syringes and placed in tubes containing dry heparin. Samples of $5 \mathrm{ml}$ blood were immediately mixed with $5 \mathrm{ml}$ of chilled perchloric acid $(30 \% \mathrm{w} / \mathrm{v})$. After centrifugation at $4^{\circ} \mathrm{C}$, the supernatant fluid was collected, neutralized with $20 \% \mathrm{KOH}$, and centrifuged again, and the resulting protein-free filtrate was kept on ice until further use. Duplicate $0.05-\mathrm{ml}$ blood samples were deproteinized with zinc sulfate and barium hydroxide solutions for measurement of glucose (23). The rest of the blood was centrifuged, and the plasma was analyzed for content of FFA (24) and immunoreactive insulin (IRI) (25).

AcAc and $\beta$-hydroxybutyrate $(\beta \mathrm{OHB})$ were estimated in the perchlorate filtrates using a fluorimetric adaptation of the enzymatic method of Williamson and Krebs (21). ${ }^{14} \mathrm{C}$ in ketone bodies was measured by the method of Mayes and Felts (26). This method permits the determination of ${ }^{14} \mathrm{C}$ activity separately in $\mathrm{AcAc}$ and $\beta \mathrm{OHB} ; \beta \mathrm{OHB}-{ }^{14} \mathrm{C}$ is converted enzymatically to $\mathrm{AcAc}-{ }^{14} \mathrm{C}$; $\mathrm{AcAc}-{ }^{14} \mathrm{C}$ is decarboxylated to acetone and $\mathrm{CO}_{2}$ which are trapped separately in a double-well flask and assayed for ${ }^{14} \mathrm{C}$ in a liquid scintillation spectrometer. Since the AcAc used in these experiments was labeled in the carbonyl carbon, only the labeled acetone produced was measured. The recovery of $\mathrm{AcAc}-{ }^{14} \mathrm{C}$ and $\beta O H B-{ }^{14} \mathrm{C}$ [DL or $\mathrm{D}(-)$ ] added to nonradioactive blood was determined with each set of determinations and found to be $88-107 \%$ for AcAc and $74-100 \%$ of $\beta \mathrm{OHB}$ [when DL$\beta \mathrm{OHB}$ was used to check recovery, only half of the ${ }^{14} \mathrm{C}$ was expected to be recovered since the assay is specific for the $\mathrm{D}(-)$ isomer]. Values for ketone radioactivity in blood samples were corrected accordingly. The determinations of unlabeled and labeled AcAc were done on the day of each experiment owing to the instability of the compound.

Blood samples for analysis of gas tensions were taken in heparinized syringes and analyzed promptly (27). Samples of expired air were collected in plastic balloons and analyzed for content of $\mathrm{CO}_{2}$ and ${ }^{14} \mathrm{CO}_{2}$ by the method of Fredrickson and Ono (28). In two diabetic dogs receiving an infusion of $\mathrm{AcAc}-{ }^{14} \mathrm{C}$, expired air was analyzed for acetone${ }^{14} \mathrm{C}$ by using the technique described by Fredrickson and Ono for expired ${ }^{14} \mathrm{CO}_{2}$ except that a mixture of lactic acid and hydrazine hydrate $(5: 2, \mathrm{v} / \mathrm{v})$ was used to trap acetone. Recovery of labeled acetone by this procedure was about $85 \%$. Results were not corrected for incomplete recovery. No detectable amounts of ${ }^{14} \mathrm{CO}_{2}$ were trapped by the lactic acid-hydrazine mixture.

The urine samples were collected in graduated cylinders kept on ice, immediately neutralized with $10 \mathrm{~N} \mathrm{NaOH}$ to avoid degradation of AcAc, and filtered. Samples of urine were assayed for ${ }^{14} \mathrm{C}$. The ${ }^{14} \mathrm{CO}_{2}$ content of urine was estimated using the procedure described elsewhere for blood (21). The ${ }^{14} \mathrm{C}$ in urine not accounted for by bicarbonate was assumed to be in ketone bodies.

Lipids were extracted from tissues in ethanol-acetone $(1: 1)$ in a blender and reextracted in chloroform-methanol (2:1). An equal volume of $0.005 \mathrm{~N}$ sulfuric acid was added to the latter extract. Lipids in the chloroform phase were separated on columns of silicic acid (29). Separated fractions containing phospholipids and neutral glycerides were saponified, and the liberated fatty acids and glycerol were separated after acidification (30). Glucose was isolated from the aqueous methanol phase as the gluconate derivative (31). The washed precipitate of proteins from the ethanol-acetone extract was dissolved in hot $20 \% \mathrm{KOH}$. Glycogen was precipitated from a $\mathrm{KOH}$ digest of fresh tissue (32) and hydrolyzed in $2.4 \mathrm{~N} \mathrm{HCl}$.

All samples were assayed for ${ }^{14} \mathrm{C}$ in a liquid scintillation spectrometer. Methanol was added when necessary to make a single-phase system in toluene containing phosphors. Quenching of radioactivity was determined with an internal standard. All analyses were performed in duplicate.

\section{Preparation of materials for injection}

Unlabeled AcAc. Sodium AcAc was prepared by thoroughly mixing $54 \mathrm{ml}$ of ethyl AcAc (Eastman Organic Chemicals, Rochester, N. Y.) with $200 \mathrm{ml}$ of $2 \mathrm{~N} \mathrm{NaOH}$. 
After $15 \mathrm{hr}$, the neutrality of the solution was checked with a $\mathrm{pH}$ paper. The solution ( $\mathrm{pH} 7.0-7.5)$ was washed three times with equal amounts of diethyl ether to remove excess ethyl AcAc. The ether, the ethanol generated by the hydrolysis, and any acetone produced by spontaneous decarboxylation of the AcAc were removed by blowing a stream of nitrogen over the solution for at least $45 \mathrm{~min}$.

Labeled ketones. Chromatographically pure ethyl AcAc$3-{ }^{14} \mathrm{C}$ (specific activity $0.046 \mathrm{mCi} / \mathrm{mg}$ ) (New England $\mathrm{Nu}-$ clear Corp., Boston, Mass.) was mixed with $100 \mu \mathrm{l}$ of ethyl acetoacetate as carrier, hydrolyzed to $\mathrm{AcAc}-3-{ }^{14} \mathrm{C}$, and purified as indicated for the unlabeled material. $\mathrm{D}(-) \beta \mathrm{OHB}-$ $3-{ }^{14} \mathrm{C}$ was prepared from $\mathrm{AcAc}-3-{ }^{14} \mathrm{C}$ with $\beta \mathrm{OHB}$ de- hydrogenase and NADH and purified by liquid/liquid extraction in a Soxhlet apparatus and paper chromatography (26). Solutions of labeled and unlabeled AcAc were used immediately after preparation and chilled with ice during the course of the infusion.

\section{Calculations ${ }^{1}$}

Concentration and specific activity of AcAc in blood were stable 1-4 hr after starting the constant infusion. The infusion was continued for at least $60 \mathrm{~min}$ after a steady state was reached, and 3-10 determinations were obtained during that period. Transport of AcAc to tissues was calculated by the following equation:

(A) Transport of AcAc $(\mu \mathrm{moles} / \mathrm{min})=\frac{\text { infusion rate of AcAc- }{ }^{14} \mathrm{C}(\mathrm{cpm} / \mathrm{min})-{ }^{14} \mathrm{C} \text { in ketones excreted in urine }(\mathrm{cpm} / \mathrm{min})}{\text { specific activity of arterial AcAc }(\mathrm{cpm} / \mu \mathrm{mole})}$

For normal dogs infused with AcAc, stable concentrations of ketones in blood were obtained 1-4 hr after starting infusions. Ketone transport to tissues was calculated by the following equation:

(B) Transport of AcAc ( $\mu$ moles $/ \mathrm{min}$ ) $=$ infusion rate of AcAc $(\mu \mathrm{moles} / \mathrm{min})$

- ketones excreted in urine ( $\mu$ moles $/ \mathrm{min}$ )

This equation assumes that endogenous production of total ketones in these animals is negligible with respect to the amount infused. This assumption is supported by the following data: (a) in seven normal fasted dogs, we found (Table VI) that the production rate of total ketones aver- aged $2.46 \mu \mathrm{moles} / \mathrm{min} \cdot \mathrm{kg}(1.96-3.56)$, whereas the infusion rates of AcAc varied between 28.0 and $77.5 \mu \mathrm{moles} / \mathrm{min} \cdot \mathrm{kg}$, and $(b)$ in five of the normal dogs, the specific activity of blood AcAc averaged $93 \pm 4 \%$ of the specific activity of infused AcAc. These data indicate that the values for AcAc transport calculated from $(B)$ are underestimated by less than $10 \%$. The amount of unlabeled ketones excreted in urine was calculated assuming that the specific activity of ketones in urine was equal to that of ketones in blood.

The efflux rate of ${ }^{14} \mathrm{CO}_{2}$ and the specific activity of $\mathrm{CO}_{2}$ in expired air became virtually constant $2-4 \mathrm{hr}$ after starting the infusion. Calculations of oxidation were made as follows :

(C) Percentage of AcAc- ${ }^{14} \mathrm{C}$ oxidized promptly to ${ }^{14} \mathrm{CO}_{2}$

$$
=\frac{100 \times \text { efflux rate of }{ }^{14} \mathrm{CO}_{2} \text { in expired air }(\mathrm{cpm} / \mathrm{min})}{\text { influx rate of } \mathrm{AcAc}_{-}{ }^{14} \mathrm{C}(\mathrm{cpm} / \mathrm{min})-{ }^{14} \mathrm{C} \text { in ketones excreted in urine }(\mathrm{cpm} / \mathrm{min})}
$$

(D) Apparent percentage of exhaled $\mathrm{CO}_{2}$ derived from rapid oxidation of AcAc

$$
=\frac{100 \times \text { specific activity of exhaled } \mathrm{CO}_{2}(\mathrm{cpm} / \mu \text { mole })}{\text { specific activity of blood AcAc }(\mathrm{cpm} / \mu \text { atom } \mathrm{C})}
$$

In normal animals, for reasons outlined above, the specific activity of the infused AcAc ( $\mathrm{cpm} / \mu$ atom C) was used instead of that of blood AcAc in the latter equation.

\section{RESULTS}

Major data obtained from an experiment on a moderately ketotic diabetic dog are presented in Fig. 1. In this experiment, a steady state was present after about 180 min. Individual results from 7 experiments on diabetic dogs and 14 experiments on normal animals are summarized in Tables I-IV.

Concentration of metabolites in blood. The diabetic dogs (Table I) showed high FFA (1.56-2.72 $\mu$ moles $/ \mathrm{ml}$ ) and glucose levels (217-524 mg/dl) and elevated ketone concentrations (1.14-18.21 $\mu$ moles $/ \mathrm{ml})$, with $\beta O H B$ AcAc ratios varying between 0.78 and 2.56 (mean $=$ 1.74). The most ketotic dogs were also acidotic. Infusion of AcAc into the normal dogs (Table III) increased their blood ketones to levels (0.49-10.58 $\mu$ moles/ $\mathrm{ml}$ ) in the diabetic range with no systematic change in the $\beta$ OHB-AcAc ratio which averaged $1.21(0.14-2.80)$ before and $0.86(0.41-1.18)$ during the infusion. The infusion of ketones also produced a rise in blood $\mathrm{pH}$ and a fall in blood glucose but no systematic changes in FFA or IRI concentrations (Fig. 2).

Specific activity of blood ketones. In three model experiments where measurements were made, the ratio of the specific activity of $\beta \mathrm{OHB}$ to that of $\mathrm{AcAc}$ was close to unity $(0.90 ; 1.00 ; 1.18)$.

Excretion of ketones in urine and expired air. The values for transport of AcAc (Tables II and IV) have been corrected for urinary losses of ketones. As shown in Fig. 3, excretion was roughly proportional to the blood ketone concentration without apparent difference between normal and diabetic animals. In most cases, less

\footnotetext{
${ }^{1}$ Nomenclature used here is that recommended by Task group on Tracer Kinetics of International Commission on Radiation Units (33).
} 

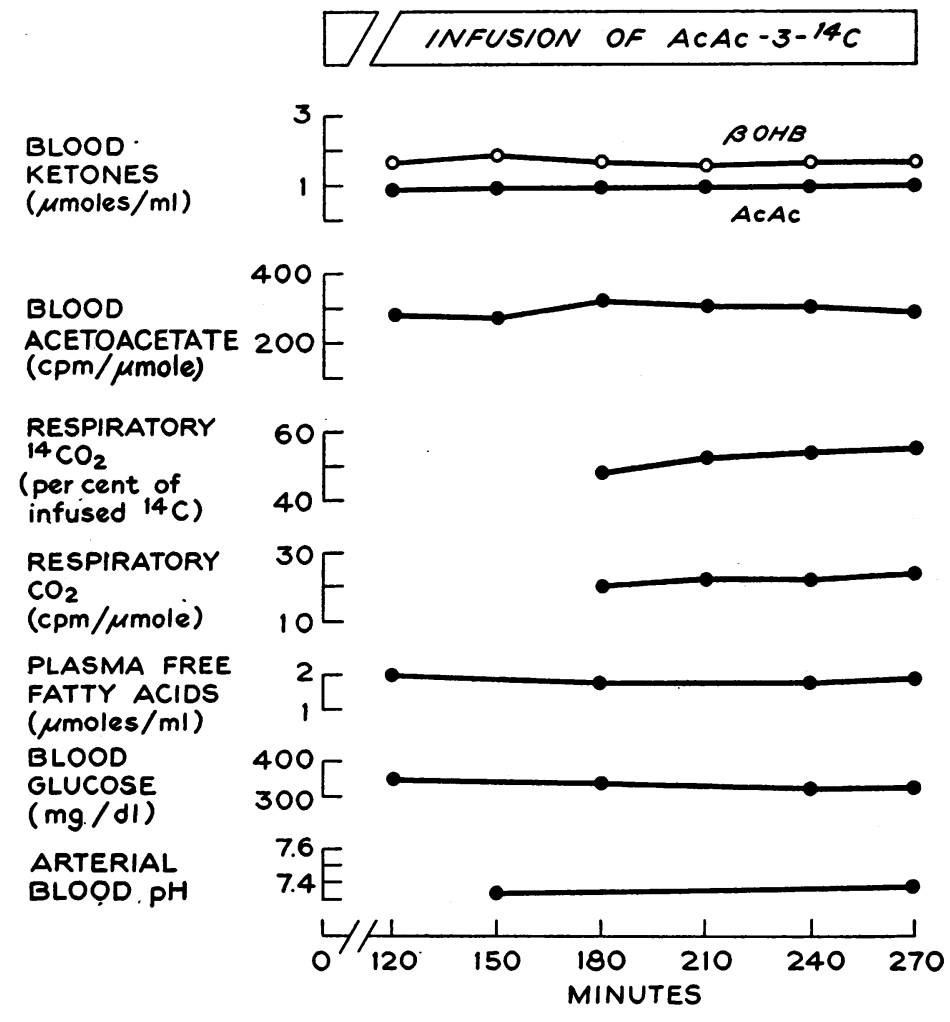

FIGURE 1 Representative experiment in a diabetic dog.

than $10 \%$ of the infused label was excreted in urine as ketones (Table II). In two diabetic dogs, acetone in expired air amounted to only 0.15 and $0.18 \%$ of transport of AcAc.
Relationship between transport and concentration of ketones. In each group, the concentration of ketones appeared to be an exponential function of transport (Fig. 4). The line for regression of ketone transport on log

TABLE I

Arterial Concentration of Metabolites in Pancreatectomized Dogs

\begin{tabular}{|c|c|c|c|c|c|c|}
\hline \multirow[b]{3}{*}{ Dog no. } & \multirow{3}{*}{$\begin{array}{l}\text { Plasma } \\
\text { FFA* }\end{array}$} & \multicolumn{5}{|c|}{ Blood } \\
\hline & & \multirow[b]{2}{*}{ Glucose* } & \multirow[b]{2}{*}{$\mathrm{pH}^{*}$} & \multirow[b]{2}{*}{ AcAct } & \multirow[b]{2}{*}{$\beta \mathrm{OHB \ddagger}$} & \multirow{2}{*}{$\frac{\beta \mathrm{OHBt}}{\mathrm{AcAc}}$} \\
\hline & & & & & & \\
\hline & Amoles $/ \mathrm{ml}$ & $m g / d l$ & & $\mu$ moles $/ \mathrm{ml}$ & 4moles $/ m l$ & $210+030$ \\
\hline $\begin{array}{l}34 \\
35\end{array}$ & $\begin{array}{l}1.87 \\
1.29\end{array}$ & $\begin{array}{l}320 \\
305\end{array}$ & $\begin{array}{l}7.29 \\
7.23\end{array}$ & $\begin{array}{l}3.00 \pm 0.29 \\
5.11 \pm 0.20\end{array}$ & $\begin{array}{r}6.30 \pm 0.35 \\
13.10 \pm 0.14\end{array}$ & $\begin{array}{l}2.10 \pm 0.30 \\
2.56 \pm 0.08\end{array}$ \\
\hline 46 & 1.58 & 401 & 7.41 & $0.64 \pm 0.04$ & $0.50 \pm 0.08$ & $0.78 \pm 0.12$ \\
\hline 43 & 2.10 & 524 & 7.33 & $0.83 \pm 0.06$ & $1.59 \pm 0.17$ & $1.92 \pm 0.22$ \\
\hline 40 & 2.72 & 490 & 7.28 & $2.08 \pm 0.18$ & $3.58 \pm 0.60$ & $1.72 \pm 0.23$ \\
\hline 50 & 1.85 & $324-$ & 7.38 & $0.98 \pm 0.09$ & $1.72 \pm 0.10$ & $1.75 \pm 0.19$ \\
\hline $50 \S$ & 2.08 & 325 & 7.56 & 1.46 & 2.27 & 1.55 \\
\hline $52 \S$ & 1.56 & 217 & 7.55 & $1.25 \pm 0.11$ & $1.92 \pm 0.11$ & $1.54 \pm 0.09$ \\
\hline
\end{tabular}

* Mean of two to three values obtained during the period of steady blood ketone radioactivity.

$\ddagger$ Mean $\pm \mathrm{SD}$ of three to six values obtained during the last $60-220 \mathrm{~min}$ of $\mathrm{AcAc}-{ }^{14} \mathrm{C}$ infusion (steady period of blood ketone radioactivity).

$\S$ Dogs made alkalotic by infusing sodium bicarbonate (see text). 
TABLE II

Transport and Oxidation of Acetoacetate in Pancreatectomized Dogs

\begin{tabular}{|c|c|c|c|c|c|c|c|c|}
\hline \multirow[b]{2}{*}{$\begin{array}{l}\text { Dog } \\
\text { no. }\end{array}$} & \multirow{2}{*}{$\begin{array}{c}\% \text { of infused } \\
\text { ketones } \\
\text { excreted } \\
\text { in urine }\end{array}$} & \multirow{2}{*}{$\begin{array}{l}\text { Specific } \\
\text { activity } \\
\text { of AcAc } \\
\text { in blood* }\end{array}$} & \multirow[b]{2}{*}{$\begin{array}{c}\text { Net } \\
\text { transport } \\
\text { of AcAc* }\end{array}$} & \multicolumn{3}{|c|}{ Respiratory $\mathrm{CO}_{2} \ddagger$} & \multirow[b]{2}{*}{$\begin{array}{l}\% \text { AcAc } \\
\text { oxidized }\end{array}$} & \multirow[b]{2}{*}{$\begin{array}{c}\% \mathrm{CO}_{2} \\
\text { from } \mathrm{AcAc}\end{array}$} \\
\hline & & & & $\begin{array}{l}\text { Efflux } \\
\text { rate } \\
\text { of } \mathrm{CO}_{2}\end{array}$ & $\begin{array}{l}\text { Efflux } \\
\text { rate } \\
\text { of }{ }^{14} \mathrm{CO}_{2}\end{array}$ & $\begin{array}{l}\text { Specific } \\
\text { activity }\end{array}$ & & \\
\hline & & cpm/matom $C$ & $\begin{array}{l}\text { mmoles/ } \\
\min \cdot \mathrm{kg}\end{array}$ & $\begin{array}{l}\mu m o l e s / \\
\min \cdot \mathrm{kg}\end{array}$ & $\begin{array}{c}\mathrm{cpm} / \\
\min \cdot \mathrm{kg}\end{array}$ & $\begin{array}{l}\text { cpm/ } \\
\text { umole }\end{array}$ & & \\
\hline 34 & 14.5 & $56.8 \pm 3.8$ & $37.7^{\circ}$ & 208 & 3000 & 14.4 & 35.1 & 25.4 \\
\hline 35 & 29.0 & $46.7 \pm 1.7$ & 38.0 & 219 & 3870 & 17.7 & 54.2 & 37.8 \\
\hline 46 & 4.0 & $110.6 \pm 7.4$ & 21.6 & 212 & 5370 & 25.3 & 56.0 & 22.9 \\
\hline 43 & 2.6 & $115.0 \pm 10.8$ & 21.1 & 275 & 6100 & 22.2 & 62.6 & 19.3 \\
\hline 40 & 4.3 & $58.0 \pm 3.0$ & 41.2 & 262 & 4610 & 17.6 & 48.2 & 30.4 \\
\hline 50 & 5.0 & $78.4 \pm 5.3$ & 30.2 & 214 & 5020 & 23.5 & 52.9 & 30.0 \\
\hline $50 \S$ & 9.4 & 66.7 & 33.9 & 231 & 4730 & 20.5 & 52.2 & 30.6 \\
\hline $52 \S$ & 4.0 & $92.7 \pm 5.6$ & 25.9 & 170 & 3620 & 21.3 & 37.7 & 22.9 \\
\hline
\end{tabular}

Data pertaining to radioactivity have been converted to influx rate of $10,000 \mathrm{cpm} / \mathrm{min} \cdot \mathrm{kg}$.

* Mean \pm SD of three to six determinations obtained during the last $60-220$ min of $A c A c-14 C$ infusion (steady period of blood ketone radioactivity).

$\ddagger$ Mean of two to six values obtained during the last $30-150 \mathrm{~min}$ of $\mathrm{AcAc}-{ }^{14} \mathrm{C}$ inf usion (steady-state period for efflux rate of ${ }^{14} \mathrm{CO}_{2}$ ).

§ Dogs made alkalotic by infusing sodium bicarbonate.

of ketone concentration is shown at the lower part of the figure. Values corresponding to normal dogs in whom hepatic ketone production was directly measured by catheterization of the hepatic and portal veins are situated on this regression line. This suggests that the same log- linear relationship between transport and concentration holds for a very wide range of concentrations from the low levels encountered in normal fasted dogs up to the high levels obtained by infusing AcAc. Fig. 4 shows clearly that all the values for diabetic animals are situ-

TABLE III

Arterial Concentration of Metabolites in Normal Dogs Infused with Acetoacetate

\begin{tabular}{|c|c|c|c|c|c|c|}
\hline \multirow[b]{3}{*}{ Dog no. } & \multirow{3}{*}{$\begin{array}{c}\text { Plasma } \\
\text { FFA* }^{*}\end{array}$} & \multicolumn{5}{|c|}{ Blood } \\
\hline & & & & & & $\beta \mathrm{OHBt}$ \\
\hline & & Glucose* & $\mathrm{pH}^{*}$ & AcAc & $\beta O H B \ddagger$ & AcAc \\
\hline & umoles $/ \mathrm{ml}$ & $m g / d l$ & & umoles $/ m l$ & umoles $/ m l$ & \\
\hline 36 & 0.62 & 97 & 7.52 & $4.80 \pm 0.30$ & $5.14 \pm 0.32$ & $1.07 \pm 0.01$ \\
\hline 37 & 0.24 & 90 & 7.49 & $0.44 \pm 0.02$ & $0.18 \pm 0.02$ & $0.41 \pm 0.05$ \\
\hline 38 & 0.34 & 110 & 7.44 & $0.29 \pm 0.01$ & $0.20 \pm 0.02$ & $0.69 \pm 0.08$ \\
\hline 39 & 0.31 & - & 7.56 & $2.07 \pm 0.07$ & $1.20 \pm 0.03$ & $0.58 \pm 0.02$ \\
\hline 41 & 0.17 & 84 & 7.68 & $2.29 \pm 0.12$ & $1.28 \pm 0.13$ & $0.56 \pm 0.06$ \\
\hline 44 & 1.03 & 49 & 7.46 & $2.84 \pm 0.04$ & $2.86 \pm 0.17$ & $1.00 \pm 0.05$ \\
\hline 45 & 0.33 & 92 & - & $2.32 \pm 0.13$ & $2.27 \pm 0.09$ & $0.98 \pm 0.03$ \\
\hline 48 & 0.16 & 98 & 7.44 & $1.05 \pm 0.06$ & $0.78 \pm 0.07$ & $0.74 \pm 0.08$ \\
\hline 49 & 0.42 & 77 & 7.54 & $0.77 \pm 0.04$ & $0.28 \pm 0.03$ & $0.36 \pm 0.05$ \\
\hline 51 & 0.29 & 57 & 7.57 & $3.30 \pm 0.14$ & $3.90 \pm 0.21$ & $1.18 \pm 0.03$ \\
\hline 53 & 0.53 & 87 & 7.55 & $1.31 \pm 0.07$ & $1.50 \pm 0.05$ & $1.14 \pm 0.05$ \\
\hline 58 & 0.44 & 75 & 7.72 & $1.23 \pm 0.05$ & $1.25 \pm 0.02$ & $1.02 \pm 0.05$ \\
\hline 65 & - & 76 & - & $5.92 \pm 0.15$ & $4.66 \pm 0.28$ & $0.79 \pm 0.06$ \\
\hline 67 & 一 & 一 & 7.52 & $1.09 \pm 0.03$ & $0.49 \pm 0.02$ & $0.45 \pm 0.04$ \\
\hline
\end{tabular}

* Mean of two or three values obtained during the period of steady ketone concentration.

$\ddagger$ Mean \pm SD of 3-10 determinations obtained during the last $60-180 \mathrm{~min}$ of the AcAc infusion (period of steady ketone concentration). 
TABLE IV

Transport and Oxidation of Acetoacetate in Normal Dogs Infused with Acetoacetate

\begin{tabular}{|c|c|c|c|c|c|c|c|c|c|}
\hline \multirow[b]{2}{*}{$\begin{array}{l}\text { Dog } \\
\text { no. }\end{array}$} & \multirow[b]{2}{*}{$\begin{array}{c}\text { AcAc } \\
\text { infused }\end{array}$} & \multirow{2}{*}{$\begin{array}{l}\text { Specific } \\
\text { activity } \\
\text { of AcAc } \\
\text { in blood* }\end{array}$} & \multirow[b]{2}{*}{$\begin{array}{l}\% \text { of infused } \\
\text { AcAc excreted } \\
\text { in urine }\end{array}$} & \multirow[b]{2}{*}{$\begin{array}{c}\text { Net } \\
\text { transport } \\
\text { of AcAc* }\end{array}$} & \multicolumn{3}{|c|}{ Respiratory $\mathrm{CO}_{2} *$} & \multirow[b]{2}{*}{$\begin{array}{l}\% \text { AcAc } \\
\text { oxidized }\end{array}$} & \multirow[b]{2}{*}{$\begin{array}{c}\% \mathrm{CO}_{2} \\
\text { from } \\
\mathrm{AcAc}\end{array}$} \\
\hline & & & & & $\begin{array}{l}\text { Efflux } \\
\text { rate } \\
\text { of } \mathrm{CO}_{2}\end{array}$ & $\begin{array}{l}\text { Efflux } \\
\text { rate } \\
\text { of }{ }^{{ }^{4} \mathrm{CO}_{2}}\end{array}$ & $\begin{array}{l}\text { Specific } \\
\text { activity }\end{array}$ & & \\
\hline & Mmoles $/ \min \cdot \mathrm{kg}$ & $\begin{array}{c}c p m / \\
\text { Matom } C\end{array}$ & & $\begin{array}{l}\text { mmoles/ } \\
\min \cdot k g\end{array}$ & 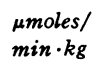 & $\begin{array}{c}c p m / \\
\min \cdot k g\end{array}$ & $\begin{array}{l}\text { cpm/ } \\
\text { umole }\end{array}$ & & \\
\hline 36 & 77.5 & - & 16.0 & 65.0 & - & - & - & - & 一 \\
\hline 37 & 26.3 & - & 0.7 & 26.0 & - & - & - & - & 一 \\
\hline 38 & 28.0 & 89.2 & 2.1 & 27.5 & 198 & 3100 & 15.7 & 31.7 & 17.6 \\
\hline 39 & 49.4 & 50.6 & 6.6 & 46.2 & 234 & 5110 & 21.8 & 54.7 & 43.0 \\
\hline 41 & 47.4 & 52.6 & 4.7 & 45.1 & 234 & 3160 & 13.5 & 33.2 & 25.6 \\
\hline 44 & 65.2 & 38.3 & 8.4 & 59.7 & 284 & 4120 & 14.5 & 44.9 & 37.9 \\
\hline 45 & 49.1 & 50.8 & 5.5 & 46.3 & 162 & 4050 & 25.0 & 42.8 & 49.2 \\
\hline 48 & 39.5 & 一 & 2.8 & 38.4 & 一 & 一 & - & - & - \\
\hline 49 & 37.4 & 66.7 & 5.1 & 35.4 & 182 & 5160 & 28.3 & 54.2 & 42.3 \\
\hline 51 & 58.3 & 42.9 & 9.6 & 52.2 & 145 & 3130 & 21.6 & 34.6 & 50.3 \\
\hline 53 & 46.0 & 54.2 & 3.2 & 44.7 & 217 & 4780 & 22.0 & 49.2 & 40.5 \\
\hline 58 & 50.9 & - & 6.8 & 47.5 & - & - & - & 一 & - \\
\hline 65 & 72.5 & - & 17.6 & 65.2 & - & - & - & - & - \\
\hline 67 & 46.7 & 53.4 & 4.8 & 44.4 & - & - & - & - & - \\
\hline
\end{tabular}

Data pertaining to radioactivity have been converted to influx rates of $10,000 \mathrm{cpm} / \mathrm{min} \cdot \mathrm{kg}$.

${ }^{*}$ Mean of three values obtained during the last hour of ketone infusion (steady-state period for efflux rate of ${ }^{14} \mathrm{CO}_{2}$ ). For dogs 38 and 39 , mean of two values recorded during the last $30 \mathrm{~min}$ of infusion.

ated below the range of normal values indicated by the 95\% confidence limits drawn on each side of the regression line.

Influence of blood $p H$ on the concentration and the rate of utilization of blood ketones. The influence of an increase in blood $\mathrm{pH}$ on the rate of ketone uptake was tested in two diabetic dogs. Dog 50 (Tables I and II) was studied during two successive stages of the same experiment. During the first stage $(0-270 \mathrm{~min})$, blood $\mathrm{pH}$ was 7.38 , the concentration of ketones was 2.72 $\mu \mathrm{moles} / \mathrm{ml}$, and transport of AcAc was $30.2 \mu$ moles/ min $\cdot \mathrm{kg}$. During the second stage $(270-330 \mathrm{~min})$, the constant infusion of labeled AcAc was continued, whereas the blood $\mathrm{pH}$ was increased to 7.56 by infusing large amounts of sodium bicarbonate. During the last 60 min of that period, the ketone concentration was 3.73 $\mu$ moles $/ \mathrm{ml}(+38 \%)$, and transport was $33.9 \mu$ moles/ $\min \cdot \mathrm{kg}(+12 \%)$. This increase in transport and in the concentration of ketones was most probably independent of the infusion of bicarbonate and corresponds to the expected aggravation of ketosis with time in an animal deprived of insulin. By referring to Fig. 4 where values from both stages of the experiment have been plotted, it can be seen that alkalinization did not alter the abnormal relationship between transport and concentration of ketones. The same conclusion can be drawn from experiment on dog 52 (Tables I and II and Fig. 4) where alkalosis ( $\mathrm{pH}$ 7.55) was produced during the entire study.
Oxidation of ketones. The fraction of AcAc taken up by tissues and promptly oxidized to $\mathrm{CO}_{2}$ averaged $43.2 \%$ $(31.7-54.7 \%)$ in normal animals, and $49.9 \%$ (35.1$62.6 \%$ ) in diabetic dogs. The difference between groups was not significant. The apparent percentage of respiratory $\mathrm{CO}_{2}$ derived from AcAc was positively correlated with transport of AcAc as shown in Fig. 5. At high rates of transport $(50-60 \mu \mathrm{moles} / \mathrm{min} \cdot \mathrm{kg}$ ), about $50 \%$ of expired $\mathrm{CO}_{2}$ could be accounted for by the oxidation of AcAc. As discussed below, excretion of ${ }^{14} \mathrm{CO}_{2}$ underestimates the actual contribution of ketones to oxidative metabolism.

Influence of glucose and insulin on peripheral metabolism of ketones. The influence of the magnitude of glucose assimilation on the rate of uptake and oxidation of ketones was tested in seven normal dogs (Fig. 6). The animals were infused at a constant rate with labeled and unlabeled AcAc (33.2-65.2 $\mu \mathrm{moles} / \mathrm{min} \cdot \mathrm{kg})$ for about $300 \mathrm{~min}$. In all animals except one, a steady concentration of ketones $(1.1-5.9 \mu \mathrm{moles} / \mathrm{ml})$ was achieved in blood. Simultaneously, a constant efflux rate of expired ${ }^{14} \mathrm{CO}_{2}$ was observed, corresponding to $35-55 \%$ of the infused ${ }^{14} \mathrm{C}$. After about $180 \mathrm{~min}$, a constant infusion of large amounts of glucose $(16-48 \mathrm{mg} / \mathrm{min} \cdot \mathrm{kg}$ as a $50 \%$ solution) and insulin $(4.8-6.7 \mathrm{mU} / \mathrm{min} \cdot \mathrm{kg}$ ) was started, preceded by a priming dose corresponding to the volume infused in $15 \mathrm{~min}$. The following changes were observed during the glucose-insulin infusion: $(a)$ reduction in blood ketone levels by an average of $35 \%(21-49)$ with 
a fall in $\beta O H B-A c A c$ ratio from 0.86 to 0.68 (no change in rate of ketone excretion by the kidney was observed which indicates that the fall in ketone concentration resulted from an increased uptake by tissues), (b) a $50 \%$ (33-67) decrease in concentration of plasma FFA, and (c) a $40 \%$ (29-51) increase in the efflux rate of expired ${ }^{14} \mathrm{CO}_{2}$.

Pattern of ketone disappearance from blood after stopping a constant infusion. A steady state of hyperketonemia was obtained in a normal dog by infusion of AcAc for $220 \mathrm{~min}$. A tracer amount of $\mathrm{AcAc}-{ }^{14} \mathrm{C}$ was simultaneously infused for the first $180 \mathrm{~min}$ and then stopped. The disappearance of labeled ketones from the blood compartment was not a single exponential function of time (Fig. 7). The rate of decay was at first rapid (with a half-life of a few minutes) and then decreased progressively. The same pattern was observed for $\beta \mathrm{OHB}-{ }^{14} \mathrm{C}$ but with slower rates. In other experiments, similar patterns were observed for ketone concentration after stopping an infusion of unlabeled AcAc.

Arteriovenous differences in ketone bodies. The arteriovenous $(\mathrm{A}-\mathrm{V})$ differences of $\mathrm{AcAc}$ and $\beta \mathrm{OHB}$
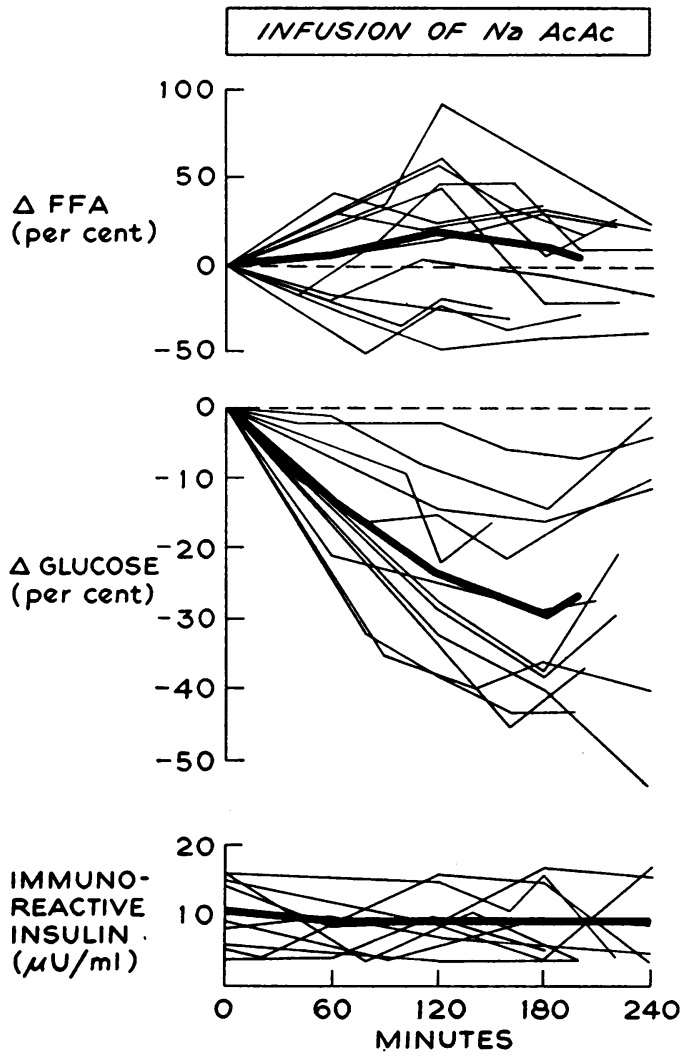

FIGURE 2 Changes in blood glucose and in plasma FFA and immunoreactive insulin during infusion of sodium AcAc into normal dogs. The very dark and thick lines represent the mean values for each plot.

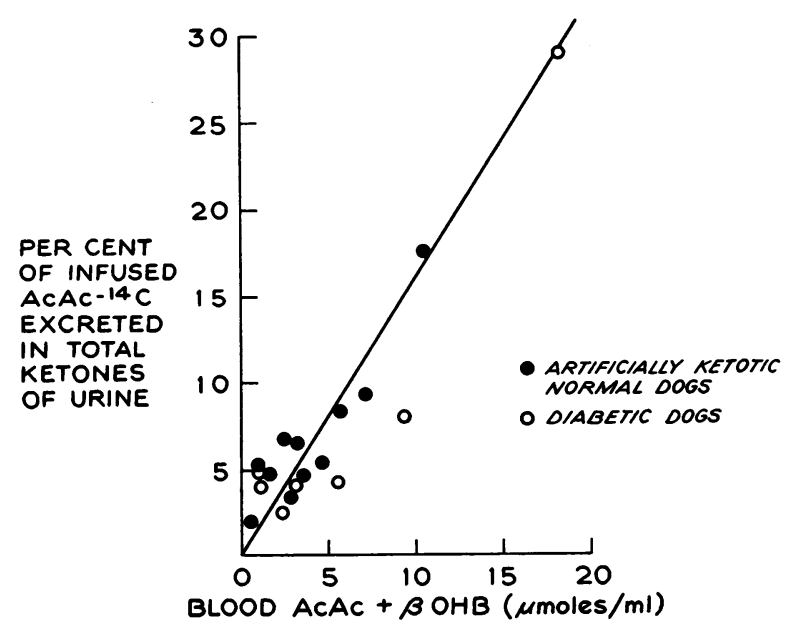

FIgURE 3 Relationship between excretion of ketones in urine and blood ketone concentration in diabetic and artificially ketotic normal dogs.

across the extrahepatic splanchnic bed or across the leg were measured in normal dogs at normal fasting levels and at high concentrations observed during infusion of AcAc (Table V). At low concentrations ( $0.040 \mu$ moles/ $\mathrm{ml})$, extraction ratio of AcAc in extra-hepatic splanchnic tissues averaged $55 \%$, whereas it amounted to only $23 \%$ at higher concentrations $(1.3 \mu$ moles $/ \mathrm{ml})$. Similar values were observed for the leg. In each experiment, extraction ratio of AcAc was higher than that of $\beta \mathrm{OHB}$.

Hepatic production of $A c A c$ and $\beta O H B$ in normal dogs. Blood concentrations and hepatic production rates of $\mathrm{AcAc}$ and $\beta \mathrm{OHB}$ were measured directly in normal animals (Table VI). AcAc accounted for $75 \%$ of the total ketone production but for only about $50 \%$ of total ketones in arterial blood.

${ }^{14} C$ in tissues. In $\operatorname{dog} 58,0.5$ and $0.2 \%$ of infused $\beta \mathrm{OHB}-{ }^{14} \mathrm{C}$ were recovered in lipids of liver and kidneys, respectively, at the end of the experiment. Estimated recovery in muscle (estimated from ${ }^{14} \mathrm{C}$ in lipids of thigh muscle with the assumption that muscle mass was $40 \%$ of body weight) was $1.1 \%$, and in adipose tissue (estimated from ${ }^{14} \mathrm{C}$ in lipids of mesenteric fat with the assumption that adipose tissue mass was $5 \%$ of body weight) was $5.5 \%$. In another normal dog infused with AcAc and AcAc- $3-{ }^{14} \mathrm{C}$ for $4 \mathrm{hr}$ (not reported in Tables III and IV), corresponding values were $2.0 \%$ for liver, $0.2 \%$ for kidney, and $1.1 \%$ for muscle. In liver and kidney, radioactivity was equally divided between neutral glycerides and phospholipids, and in both tissues $70-80 \%$ was in the fatty acyl moieties of these lipids. Small amounts of ${ }^{14} \mathrm{C}$ were found in glycogen $(0.1 \%$ in liver, $0.1 \%$ in kidneys, and $0.5 \%$ in muscle) and in tissue glucose $(0.2 \%$ in liver and $0.1 \%$ in kidneys $)$. Substantial quantities were, however, recovered in proteins $(2.0 \%$ 

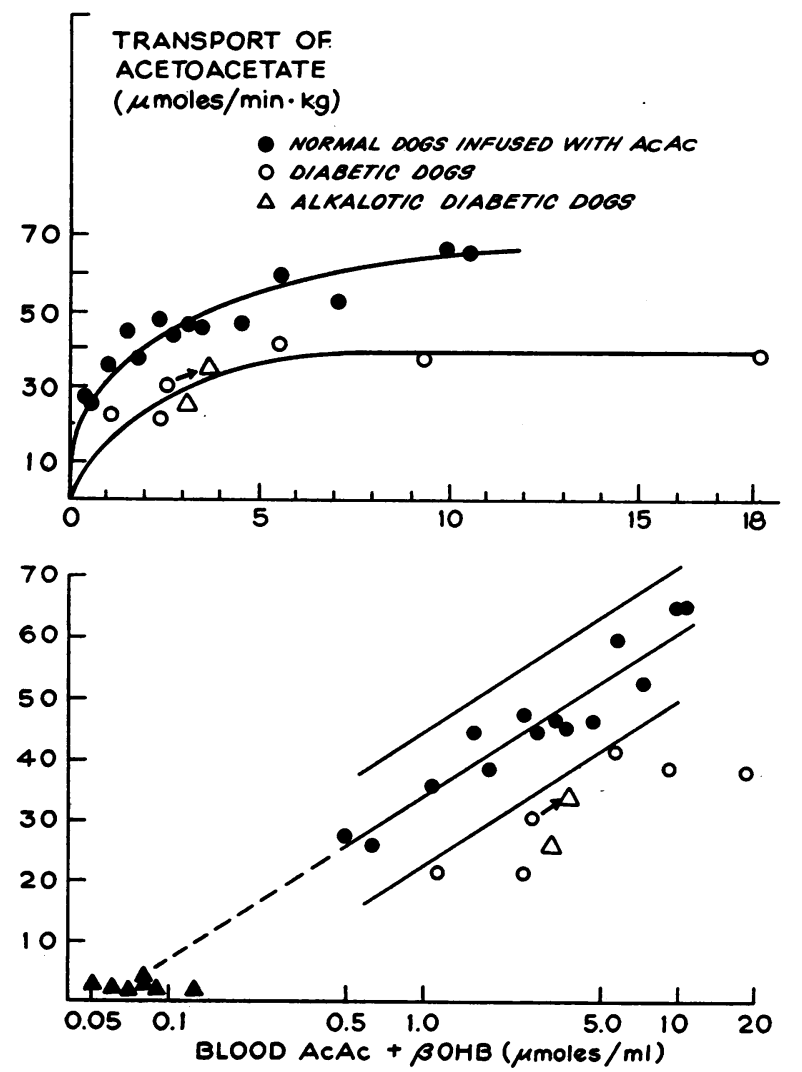

FIGURE 4 Relationship between transport and concentration of ketones in normal and diabetic dogs. Upper graph on Cartesian coordinates shows exponential relationship; lower graph shows some data with transport plotted against log concentration of ketones, together with values from direct measurement of hepatic production of ketones in normal dogs $(\Delta)$. Lines on lower part of figure indicate regression and $95 \%$ confidence limits for values in normal animals. Arrow indicates transition from normal $\mathrm{pH}$ to alkalotic state in $\operatorname{dog} 50$.

in liver, $0.4 \%$ in kidneys, and $9.4 \%$ in muscle). Thus, about $20 \%$ of the infused ${ }^{14} \mathrm{C}$ was recovered in lipids and proteins of the four tissues studied.

\section{DISCUSSION}

Our data show that rapid uptake and oxidation of ketones takes place in tissues. The extrahepatic splanchnic area and the leg tissues, for example, extract ketones from blood very efficiently. Rapid interconversion of $\mathrm{AcAc}$ and $\beta \mathrm{OHB}$ must also take place in tissues since the specific activity of the two compounds became equal during the constant infusion of $\mathrm{AcAc}-{ }^{14} \mathrm{C}$. This indicates that the rate of transport of AcAc represents that of total ketone bodies. Bergman, Kon, and Katz have made the same observation in sheep (3). The data presented in Table V and Fig. 7 suggest that AcAc is utilized more rapidly than $\beta O H B$. However, this is difficult to ascer- tain because of the interconvertibility of the two compounds. Williamson and Krebs observed no difference in rates of uptake of $\mathrm{AcAc}$ and $\beta \mathrm{OHB}$ (corrected for conversion into the other compound) in a perfused heart preparation in vitro (34), and Hagenfeldt and Wahren found similar extraction ratios for AcAc and $\beta O H B$ across the region drained by the deep veins of the human forearm at rest (35). In contrast, values similar to those observed in this study have been obtained for the region drained by the femoral vein in resting and exercising young men (36). This is consistent with the observation that the ratio of arterial concentration to splanchnic production rate of AcAc is lower than that of $\beta O H B$ in dogs (Table VI) and humans (37).

The main observations of this study compare the peripheral utilization of ketone bodies in normal and diabetic dogs. To make this comparison possible, the control dogs were made ketotic by infusions of sodium AcAc. Ideally, the control dogs should have been infused with a mixture of AcAc and $\beta O H B$ identical with that secreted into the hepatic vein in diabetic animals. Unfortunately, this is difficult to accomplish since $D(-) \beta O H B$ (the physiological isomer) is not available commercially and is cumbersome to prepare in large quantities. Use of DL$\beta \mathrm{OHB}$ would have been inappropriate since it is known that the $\mathrm{L}(+)$ isomer is oxidized by a different enzymatic pathway $(38,39)$ and at a different rate (35) than the D ( - ) form. Infusion of AcAc into the normal animals did not alter their $\beta O H B-A c A c$ ratio which was on the average about half that of the diabetic animals. This difference probably reflects the more reduced redox state of mitochondria in diabetic tissues. Another consequence of the infusion of sodium AcAc in the control dogs was a rise in blood $\mathrm{pH}$. Since alkalinization of the blood of the diabetic animals did not change significantly the rate of uptake of ketones, it is unlikely that this influenced our results. Bergman and Kon, using techniques similar to ours, compared nondiabetic ketotic sheep with

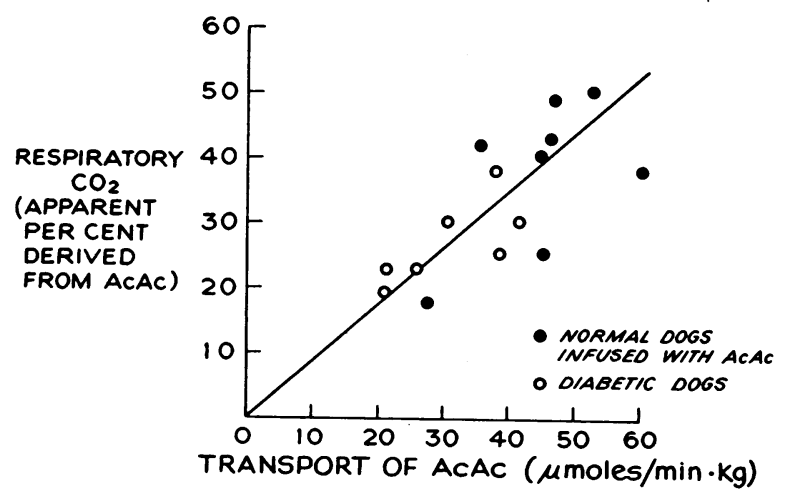

FIgURE 5 Relationship between transport of AcAc and percentage $\mathrm{CO}_{2}$ derived from AcAc in normal and diabetic dogs. 
normal sheep infused with AcAc and were unable to detect any difference in rate of uptake of ketones between the two groups (40). The evidence available, therefore, suggests that our dogs infused with AcAc are appropriate controls for the diabetic animals.

In both groups studied, the concentration of ketones was an exponential function of transport, but for any value less than $30 \mu$ moles $/ \mathrm{min} \cdot \mathrm{kg}$, the total ketone concentration in the diabetic dogs was about 3 times that in normal dogs. Moreover, the maximal capacity to utilize ketones did not exceed $40 \mu \mathrm{moles} / \mathrm{min} \cdot \mathrm{kg}$ in the pancreatectomized animals, whereas it amounted to about $70 \mu \mathrm{moles} / \mathrm{min} \cdot \mathrm{kg}$ in the normal dogs. It is thus clear that a definite impairment of mechanisms for utilizing ketones exists in diabetic dogs and contributes to ketosis. At the highest rates of transport observed in diabetic dogs with uncontrolled hyperglycemia and high rates of transport of FFA, total ketone concentration would have been only about 2 mmoles/liter if capacity to remove ketones had remained normal (Fig. 4). Actual values were

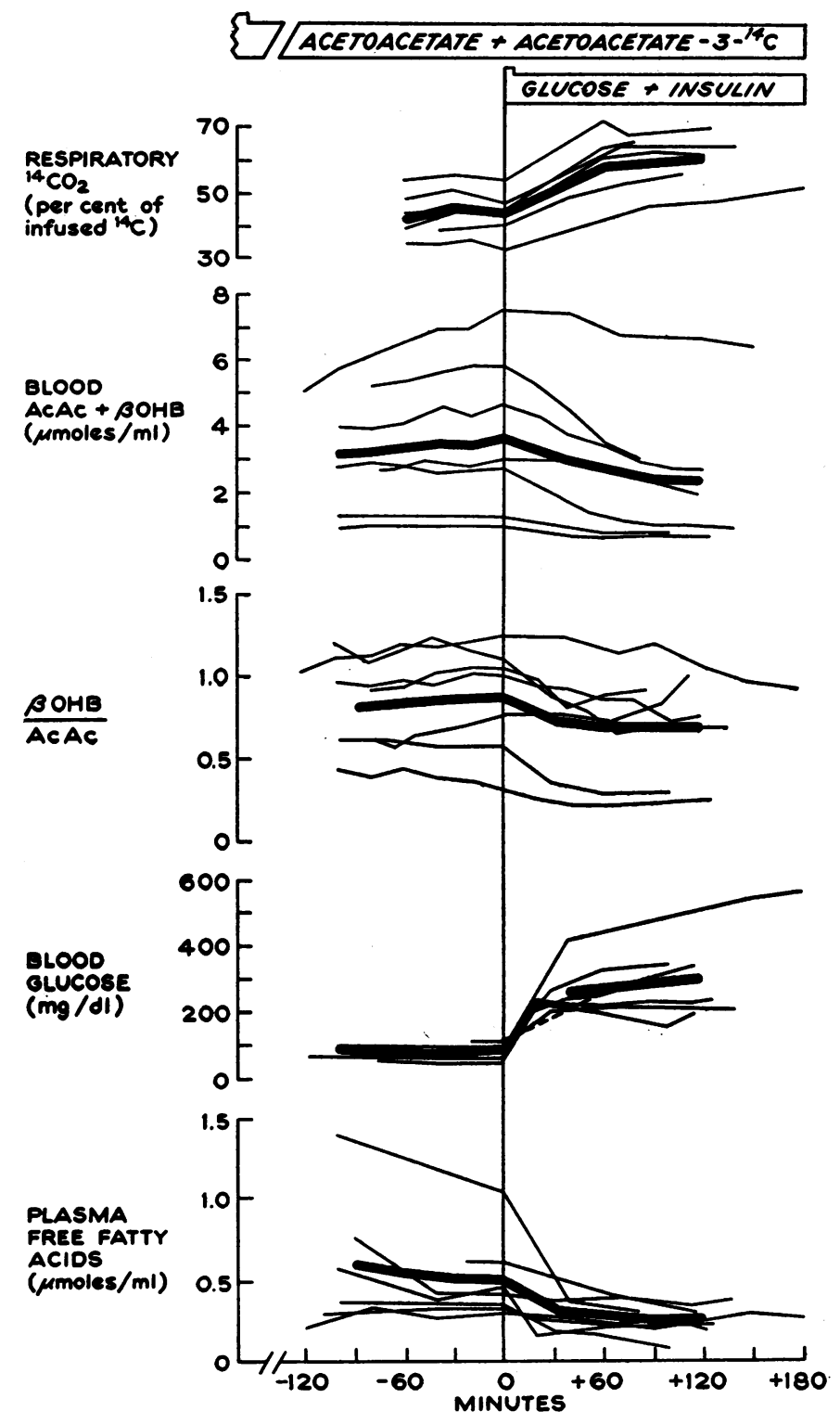

Figure 6 Effect of glucose and insulin on concentration and oxidation of ketone bodies in normal dogs infused with AcAc. The thick lines represent mean values. 
6-18 mmoles/liter. It is reasonable to conclude, therefore, that diabetic ketoacidosis would not occur in the absence of the observed defect in utilization.

On an average, about $50 \%$ of the infused $\mathrm{AcAc}_{-}{ }^{14} \mathrm{C}$ appeared as ${ }^{14} \mathrm{CO}_{2}$ in the expired air irrespective of the quantity of AcAc utilized and without difference between the two groups. Similar values were obtained in normal and ketotic sheep by Bergman et al. (3). It must be assumed that the radioactivity which did not appear in expired $\mathrm{CO}_{2}$ was incorporated into other compounds. At the end of sample experiments, about $11 \%$ of the infused radioactivity was estimated to be in proteins (mainly in muscle), about $8 \%$ in lipids (mainly in adipose tissue but some in liver, muscle, and kidney) and a small amount in tissue glucose and glycogen. Since there is no net conversion of acetyl CoA-carbon to amino acids or trioses, the ${ }^{14} \mathrm{C}$ in proteins and lipid-glycerol must have resulted from exchange processes. For protein, this could occur at several steps of the citric acid cycle such as the reversible conversion of $\alpha$-ketoglutarate to glutamate and of oxaloacetate to aspartate. Exchange reactions can also account for appearance of ${ }^{14} \mathrm{C}$ in glucose and glycogen. Our estimates of oxidation to $\mathrm{CO}_{2}$ are artifactually low to the extent of these isotopic exchanges, which appear to represent at least $10-15 \%$ of the infused ${ }^{14} \mathrm{C}$. Since our isotopic data show that at high rates of transport of ketones $(40-60 \mu \mathrm{moles} / \mathrm{min} \cdot \mathrm{kg}$ ), the percentage of expired $\mathrm{CO}_{2}$ which is derived from oxidation of AcAc approaches $50 \%$, the actual value probably exceeds $60 \%$ of the total $\mathrm{CO}_{2}$ production. That the fate of ${ }^{14} \mathrm{C}$ in compounds metabolized in gluconeogenic tissues can differ from net fate of the substance has recently been reemphasized $(37,41)$. The present results indicate that similar phenomena occur in other tissues. The conversion of $\mathrm{AcAc}-{ }^{14} \mathrm{C}$ to lipids pre-

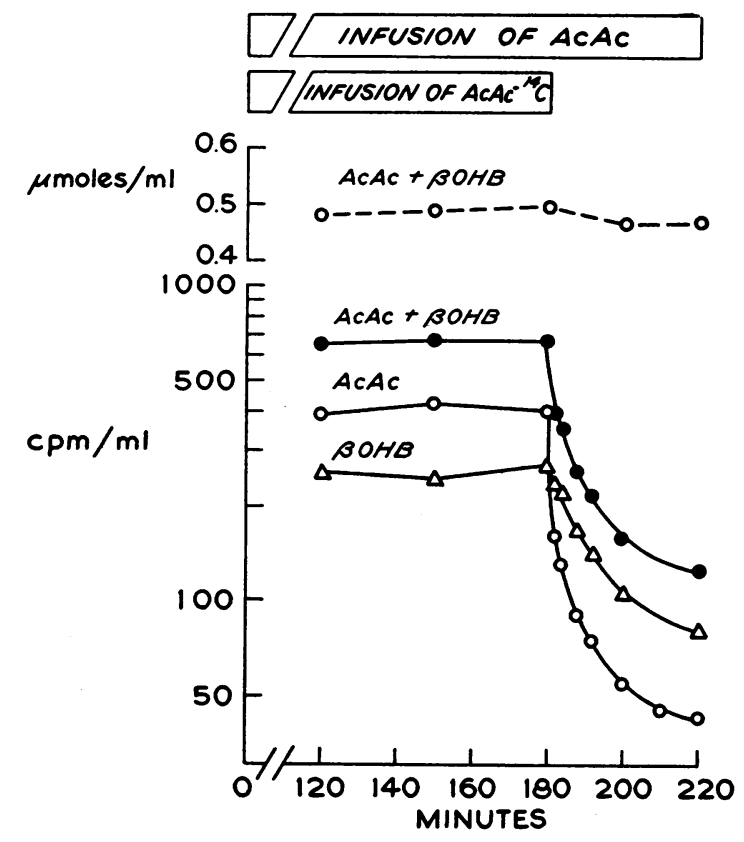

Figure 7 Pattern of disappearance of labeled ketone bodies from blood at the end of a constant infusion of $\mathrm{AcAc}-{ }^{14} \mathrm{C}$ in a normal dog infused with AcAc.

sumably represents net synthesis of fatty acids from acetyl CoA and appeared to be a substantial pathway in normal animals under the conditions of the experiment. Unfortunately, no such information was obtained in the diabetics.

We did not test whether exogenous insulin could correct the defect in maximal capacity to utilize ketones in diabetic dogs because its administration would inhibit production of ketones by the liver. This would reduce the ketone concentration and make it very difficult to

TABLE V

Arteriovenous Differences in Concentration of Ketone Bodies

\begin{tabular}{|c|c|c|c|c|c|c|c|}
\hline \multirow[b]{2}{*}{ Group } & \multirow[b]{2}{*}{$\begin{array}{c}\text { No. of } \\
\text { experiments }\end{array}$} & \multirow[b]{2}{*}{ Metabolite } & \multicolumn{3}{|c|}{ Concentration } & \multirow[b]{2}{*}{$A-V$} & \multirow[b]{2}{*}{$\frac{A-V}{A}$} \\
\hline & & & Artery & $\begin{array}{c}\text { Femoral } \\
\text { vein }\end{array}$ & $\begin{array}{l}\text { Portal } \\
\text { vein }\end{array}$ & & \\
\hline Normal & 8 & $\begin{array}{l}\text { AcAc } \\
\beta O H B\end{array}$ & $\begin{array}{l}0.040 \pm 0.006 \\
0.033 \pm 0.004\end{array}$ & $\mu m$ & $\begin{array}{l}. \mathrm{ml} \\
0.019 \pm 0.006 \\
0.028 \pm 0.003\end{array}$ & $\begin{array}{l}0.021 \pm 0.004 \\
0.006 \pm 0.001\end{array}$ & $\begin{array}{l}0.55 \pm 0.10 \\
0.16 \pm 0.04\end{array}$ \\
\hline $\begin{array}{l}\text { Normal infused } \\
\text { with AcAc }\end{array}$ & 4 & $\begin{array}{l}\mathrm{AcAc} \\
\beta \mathrm{OHB}\end{array}$ & $\begin{array}{ll}1.30 & \pm 0.35 \\
0.67 & \pm 0.13\end{array}$ & $\begin{array}{l}1.03 \pm 0.30 \\
0.68 \pm 0.14\end{array}$ & & $\begin{array}{rr}0.27 & \pm 0.09 \\
-0.01 & \pm 0.01\end{array}$ & $0.23 \pm 0.07$ \\
\hline $\begin{array}{l}\text { Normal infused } \\
\text { with AcAc }\end{array}$ & 3 & $\begin{array}{l}\text { AcAc } \\
\beta \mathrm{OHB}\end{array}$ & $\begin{array}{l}1.65 \pm 0.43 \\
0.82 \pm 0.18\end{array}$ & & $\begin{array}{ll}1.32 & \pm 0.41 \\
0.80 & \pm 0.18\end{array}$ & $\begin{array}{l}0.33 \pm 0.15 \\
0.02 \pm 0.01\end{array}$ & $\begin{array}{l}0.20 \pm 0.08 \\
0.02 \pm 0.02\end{array}$ \\
\hline
\end{tabular}

In each experiment, three to seven determinations obtained over a $60-120$ min period were averaged. Values in the table are the mean \pm SEM of all experiments in each group. 
TABLE VI

Arterial Concentration and Rates of Hepatic Production of Ketone Bodies

in Normal Postabsorptive Dogs

\begin{tabular}{|c|c|c|c|}
\hline & & & $\beta \mathrm{OHB}$ \\
\hline & AcAc & $\beta \mathrm{OHB}$ & AcAc \\
\hline Arterial concentration ( $\mu$ moles $/ m l$ ) & $0.044 \pm 0.008$ & $0.036 \pm 0.002$ & $0.82 \pm 0.02$ \\
\hline Hepatic production rate $(\mu m o l e s / \min \cdot k g)$ & $1.83 \pm 0.18$ & $0.63 \pm 0.07$ & $0.34 \pm 0.07$ \\
\hline
\end{tabular}

In each experiment, three to six determinations obtained over a 60-120 min period were averaged.

Figures in the table are mean \pm SEM for seven experiments.

detect an effect of insulin on peripheral uptake. ${ }^{2}$ Therefore, we tested the action of insulin on ketone uptake using animals in which the inflow of ketones into the blood compartment could be maintained. Normal animals infused at a constant rate with AcAc in large amounts fulfilled these conditions. Indeed, their endogenous production of ketones was negligible compared with the amount infused. Under these experimental conditions, large amounts of insulin and glucose produced a $35 \%$ reduction in blood ketone concentration, indicating an equivalent increase in turnover rate (Fig. 6). Moreover, insulin and glucose increased significantly the fraction of $\mathrm{AcAc}-{ }^{14} \mathrm{C}$ which appeared in $\mathrm{CO}_{2}$. These data are in apparent conflict with the observation that the fractional oxidation of ketones in diabetic dogs was not significantly different from that in normal animals. It should be pointed out, however, that there was substantial variation in the percentage of ketones converted to $\mathrm{CO}_{2}$ in both groups so that the influence of diabetes might be difficult to detect. The apparent increase in oxidation of AcAc may represent reduction in exchange reactions leading to incorporation of ${ }^{14} \mathrm{C}$. This interpretation is supported by the report of Söling, Zahlten, Reinold, and Willms that glucose decreased incorporation of $\mathrm{AcAc}-{ }^{14} \mathrm{C}$ into glycogen and glyceride-glycerol in rat epididymal adipose tissue in vitro (42).

Many studies have been devoted to the question of the role of insulin in regulating ketone uptake by tissues. As early as in 1928, it was postulated by Shaffer (quoted by Campbell and Best [4]) that ketosis could be caused by decreased rate of utilization of ketones in peripheral tissues with or without change in rate of production by the liver. However, numerous studies which appeared in the 1930's concluded almost unanimously that neither diabetes nor insulin had any influence on peripheral utilization (4). More recent literature, however, contains data that lead to opposite conclusions. Scow and Chernick observed that the

\footnotetext{
${ }^{2}$ If a steady state could be obtained, the effect of small continuous infusions of insulin into diabetic dogs might provide quantitative information on the ability of insulin to correct the defect in utilization.
}

clearance of ketones from blood after single intravenous injection of $\mathrm{D}(-) \beta \mathrm{OHB}$ or AcAc was impaired in pancreatectomized rats and was restored to normal by administration of insulin (20). Söling, Garlepp, and Creutzfeldt confirmed the existence of a relationship between glucose assimilation and ketone uptake in eviscerated, nephrectomized rats infused with glucose and AcAc at constant rates. They showed in fasted, starved, or alloxan-diabetic rats that increase in the rate of glucose infusion (with or without insulin) enhanced the uptake of AcAc by tissues (43).

The in vitro approach to the problem with various tissues has not given uniform results. Beatty and coworkers (17-19) found that both diaphragm and skeletal muscle fibers from diabetic rats took up and oxidized less AcAc than diaphragm and fibers from control rats. Addition of insulin alone or glucose and insulin enhanced the uptake of AcAc by muscle from both control and diabetic rats, but glucose alone was without effect. Insulin increased the production of ${ }^{14} \mathrm{CO}_{2}$ from labeled AcAc but had no effect on the percentage of incorporated AcAc appearing as $\mathrm{CO}_{2}$. Neptune, Sudduth, Fash, and Reish showed that glucose stimulates to a small extent the oxidation of $\beta \mathrm{OHB}$ by rat diaphragm but has no effect on the oxidation of AcAc (44). In contrast, Williamson and Krebs observed that insulin with or without glucose inhibited the removal and the oxidation of AcAc by the perfused rat heart (34.) Recently, Söling et al. (42) showed that glucose enhanced the uptake of $\mathrm{AcAc}$ and $\beta \mathrm{OHB}$ by rat adipose tissue, stimulated the conversion of ketones into fatty acids and inhibited ketone oxidation. These effects were increased by insulin. Finally, several authors have observed that glucose stimulates oxidation of ketones in rat brain (45-47).

The available literature contains very little quantitative information on the utilization of ketones in intact animals. Bates, Krebs, and Williamson (48) measured the half-life of ketones in rats from the decline in specific activity of $\beta O H B$ in blood after a single intravenous injection of $\mathrm{D}(-) \beta \mathrm{OHB}-{ }^{14} \mathrm{C}$. Their data show that the average half-time is $3.4 \mathrm{~min}$ in normal fed rats, 
$11.7 \mathrm{~min}$ in rats starved $48 \mathrm{hr}$, and $18.6 \mathrm{~min}$ in alloxandiabetic rats. The average ketone concentration was, respectively, $0.18,1.96$, and $9.4 \mu \mathrm{moles} / \mathrm{ml}$. These data do not permit comparison of removal capacities of peripheral tissues in normal and diabetic states because of the great difference in ketone concentrations among the three groups. Indeed, our data in dogs, those of Nelson, Grayman, and Mirsky in rats (8) and those of Wick and Drury in rabbits (9) indicate that the turnover rate of ketones decreases (half-time increases) as the concentration in blood rises. The work of Bates et al. (48) raises another comment. It is probably hazardous to calculate half-lifetimes from an apparent exponential rate of removal of labeled ketones in blood after pulse injection. When disappearance of labeled ketones from blood was measured at short intervals after stopping a constant infusion of $\mathrm{AcAc}-{ }^{14} \mathrm{C}$, we found that removal was not a single exponential function of time, thus preventing simple calculation of turnover rate (Fig. 7). Yet, our technique has the advantage of providing for complete equilibration of the label into its space of distribution at the start which is not the case with single injection techniques. The type of curve we obtained on semilogarithmic coordinates suggests recycling of ${ }^{14} \mathrm{C}$, but this cannot be the sole explanation since similar curves were obtained with unlabeled ketones. The results could be explained by variable rates of equilibration of ketones in different compartments or tissues with ketones in blood.

Uncontrolled diabetes mellitus is not the only condition in which decreased utilization of ketones contributes to ketosis. Recent studies from this laboratory have shown that ketosis in adults with glycogenosis type I (glucose-6-phosphatase deficiency) can be ascribed almost exclusively to defective peripheral utilization (49). This disease resembles uncontrolled diabetes in several features: reduced utilization of glucose, low insulin levels, and high concentrations of FFA. In contrast, utilization of ketones is unimpaired during the hypoglycemic ketosis of pregnant sheep (40).

Our data provide no information on how insulin (or the changes in glucose utilization it induces) regulates the utilization of ketones in peripheral tissues. One likely possibility is that insulin acts by decreasing the concentration and the rate of oxidation of FFA which might compete with ketones as a fuel. If this were true, then the high concentration of FFA in diabetes would be the cause of both the overproduction and the underutilization of ketones. Another possibility has been suggested by Hatefi and Fakouhi (50) who showed that the oxidation of AcAc by heart mitochondria is controlled by the concentration of inorganic phosphate, ADP and ATP. Through reactions at the level of substrate phosphorylation, inorganic phosphate and ADP reduce the mitochondrial concentration of succinyl CoA which is required for activation and subsequent oxidation of AcAc. They have suggested that the inhibition of AcAc oxidation by inorganic phosphate might play a role in the underutilization of ketones by diabetic tissues since serum inorganic phosphate levels are increased in diabetes and revert to normal when insulin is given.

Recent studies of Bieberdorf, Chernick, and Scow (51) indicate that suppression of ketogenesis by insulin is not entirely dependent upon inhibition of lipolysis in adipose tissue. Thus, it appears that insulin rapidly inhibits ketosis at multiple sites involving rates of fat mobilization from adipose tissue and the hepatic production and peripheral utilization of ketone bodies.

\section{ACKNOWLEDGMENTS}

We thank B. Carlander, C. Drakes Benjamin, D. Gobat, and L. Hatam for expert technical assistance.

These studies were supported by U. S. Public Health Service Grant HE-06285.

\section{REFERENCES}

1. Balasse, E. O., and R. J. Havel. 1970. Turnover rate and oxidation of ketone bodies in normal and diabetic dogs. Diabetologia. 6: 36.

2. Crandall, L. A., Jr., H. B. Ivy, and C. J. Ehni. 1940. Hepatic acetone body production in the dog during fasting and fat feeding. Amer. J. Physiol. 131: 10.

3. Bergman, E. N., K. Kon, and M. L. Katz. 1963. Quantitative measurements of acetoacetate metabolism and oxidation in sheep. Amer. J. Physiol. 205: 658.

4. Campbell, J., and C. H. Best. 1956. Physiologic aspects of ketosis. Metab. Clin. Exp. 5: 95.

5. Van Itallie, T. B., and S. S. Bergen, Jr. 1961. Ketogenesis and hyperketonemia. Amer. J. Med. 31: 909.

6. Krebs, H. A. 1966. The regulation of the release of ketone bodies by the liver. Advan. Enzyme Regul. 4: 339.

7. Wieland, O. 1968. Ketogenesis and its regulation. $A d-$ van. Metab. Disord. 3: 1.

8. Nelson, N., I. Grayman, and I. A. Mirsky. 1941. The utilization of acetone bodies. IV. The relation between concentration and the rate of $\beta$-hydroxybutyric acid utilization by the rat. J. Biol. Chem. 140: 361.

9. Wick, A. N., and D. R. Drury. 1941. The effect of concentration on the rate of utilization of $\beta$-hydroxybutyric acid by the rabbit. J. Biol. Chem. 138: 129 .

10. Blixenkrone-Moller, N. 1938. Uber den Abbau von Ketonkörpern. Hoppe-Seyler's Z. Physiol. Chem. 253: 261.

11. Chaikoff, I. L., and S. Soskin. 1928. The utilization of acetoacetic acid by normal and diabetic dogs before and after evisceration. Amer. J. Physiol. 87: 58.

12. Friedemann, T. E. 1936. The metabolism of sodium acetoacetate intravenously injected into dogs. J. Biol. Chem. 116: 133.

13. Dye, J. A., and J. L. Chidsey. 1939. Ketone body-total carbohydrate utilization ratios and their relation to the problem of ketosis. Amer. J. Physiol. 127: 745.

14. Stadie, W. C., J. A. Zapp, Jr., and F. D. W. Lukens. 1940. The effect of insulin upon the ketone metabolism of normal and diabetic cats. J. Biol. Chem. 132: 423. 
15. Barnes, R. H., D. R. Drury, P. O. Greeley, and A. N. Wick. 1940. Utilization of the ketone bodies in normal animals and in those with ketosis. Amer. J. Physiol. 130: 144 .

16. Koehler, A. E., E. Windsor, and E. Hill. 1941. Acetone and acetoacetic acid studies in man. J. Biol. Chem. 140: 811.

17. Beatty, C. H., R. D. Peterson, R. M. Bocek, and E. S. West. 1959. Acetoacetate and glucose uptake by diaphragm and skeletal muscle from control and diabetic rats. J. Biol. Chem. 234: 11.

18. Beatty, C. H., A. Marcó, R. D. Peterson, R. M. Bocek, and E. S. West. 1960. Acetoacetic acid metabolism by skeletal muscle fibers from control and diabetic rats. J. Biol. Chem. 235: 2774.

19. Beatty, C. H., R. D. Peterson, R. M. Bocek, and E. S. West. 1964. The effect of insulin and deprivation of food on metabolism of acetoacetic acid by muscle. J. Biol. Chem. 239: 2106.

20. Scow, R. O., and S. S. Chernick. 1960. Hormonal control of protein and fat metabolism in the pancreatectomized rat. Recent Progr. Hormone Res. 16: 497.

21. Basso, L. V., and R. J. Havel. 1970. Hepatic metabolism of free fatty acids in normal and diabetic dogs. J. Clin. Invest. 49: 537.

22. Combes, B. 1960. Estimation of hepatic flow in man and in dogs by $\mathrm{I}^{131}$-labeled rose bengal. Simultaneous comparison with sulfobromophthalein sodium. J. Lab. Clin. Med. 56: 537.

23. Saifer, A., and S. Gerstenfeld. 1958. The photometric microdetermination of blood glucose with glucose oxidase. J. Lab. Clin. Med. $51: 448$.

24. Trout, D. L., E. H. Estes. Jr., and S. J. Friedberg. 1960. Titration of free fatty acids of plasma: a study of current methods and a new modification. J. Lipid Res. 1: 199.

25. Morgan, C. R., and A. Lazarow. 1963. Immunoassay of insulin; two antibody system. Plasma insulin levels of normal, subdiabetic and diabetic rats. Diabetes. 12: 115 .

26. Mayes, P. A., and J. M. Felts. 1967. Determination of ${ }^{14} \mathrm{C}$-labelled ketone bodies by liquid-scintillation counting. Biochem. J. 102: 230.

27. Severinghaus, J. W., and A. F. Bradley. 1958. Electrodes for blood $\mathrm{pO}_{2}$ and $\mathrm{pCO}_{2}$ determination. J. Appl. Physiol. 13: 515 .

28. Fredrickson, D. S., and K. Ono. 1958. An improved technique for assay of $\mathrm{C}^{14} \mathrm{O}_{2}$ in expired air using the liquid scintillation counter. J. Lab. Clin. Med. 51: 147.

29. Havel, R. J., J. M. Felts, and C. M. Van Duyne. 1962. Formation and fate of endogenous triglycerides in blood plasma of rabbits. J. Lipid Res. 3: 297.

30. Carlson, L. A. 1963. Determination of serum triglycerides. J. Atheroscler. Res. 3: 334.

31. Blair, A., and S. Segal. 1960. The isolation of blood glucose as potassium gluconate. J. Lab. Clin. Med. 55: 959

32. Good, C. A., H. Kramer, and M. Somogyi. 1933. The determination of glycogen. J. Biol. Chem. 100: 485.

33. Brownell, G. L., M. Berman, and J. S. Robertson. 1968. Nomenclature for tracer kinetics. Int. J. Appl. Radiat. Isotop. 19: 249.

34. Williamson, J. R., and H. A. Krebs. 1961. Acetoacetate as fuel of respiration in the perfused rat heart. Biochem. J. 80: 540 .

35. Hagenfeldt, L., and J. Wahren. 1968. Human forearm muscle metabolism during exercise. III. Uptake, release and oxidation of $\beta$-hydroxybutyrate and observations on the $\beta$-hydroxybutyrate/acetoacetate ratio. Scand. J. Clin. Lab. Invest. 21: 314.

36. Havel, R. J., N. Segel, and E. O. Balasse. 1969. Effect of 5-methylpyrazole-3-carboxylic acid (MPCA) on fat mobilization, ketogenesis and glucose metabolism during exercise in man. In International Symposium on Drugs Affecting Lipid Metabolism, 3rd, Milan, 1968. Proceedings. W. L. Holmes, L. A. Carlson, and R. Paoletti, editors. Plenum Publishing Corporation, New York. 105.

37. Havel, R. J., J. P. Kane, E. O. Balasse, N. Segel, and L. V. Basso. 1970. Splanchnic metabolism of free fatty acids and production of triglycerides of very low density lipoproteins in normotriglyceridemic and hypertriglyceridemic humans. J. Clin. Invest. 49: 2017.

38. Lehninger, A. L., and G. D. Greville. 1953. The enzymic oxidation of d- and 1- $\beta$-hydroxybutyrate. Biochim. Biophys. Acta. 12: 188.

39. McCann, W. P. 1957. The oxidation of ketone bodies by mitochondria from liver and peripheral tissue. $J$. Biol. Chem. 226: 15.

40. Bergman, E. N., and K. Kon. 1964. Acetoacetate turnover and oxidation rates in ovine pregnancy ketosis. Amer. J. Physiol. 206: 449.

41. Krebs, H. A., R. Hems, M. J. Weidemann, and R. N. Speake. 1966. The fate of isotopic carbon in kidney cortex synthesizing glucose from lactate. Biochem. J. 101: 242.

42. Söling, H. D., R. Zahlten, W. V. Reimold, and B. Willms. 19\%0. Utilization of ketone bodies by adipose tissue and its regulation by carbohydrate metabolism. Horm. Metab. Res. 2: 56.

43. Söling, H. D., H. J. Garlepp, and W. Creutzfeldt. 1965. Die wirkung von insulin und glucose auf die ketonkörperaufnahme total eviscerierter, normaler, hungernder und alloxandiabetischer ratten. Biochim. Biophys. Acta. 100: 530 .

44. Neptune, E. M., Jr., H. C. Sudduth, F. J. Fash, and J. J. Reish, Jr. 1961. Metabolism of $\beta$-hydroxybutyrate and acetoacetate by excised rat diaphragm and diaphragm homogenate. Amer. J. Physiol. 201: 235.

45. Jowett, M., and J. H. Quastel. 1935. Studies in fat metabolism. III. The formation and breakdown of acetoacetic acid in animal tissues. Biochem. J. 29: 2181.

46. Openshaw, H., and W. M. Bortz. 1968. Oxidation of glucose, acetoacetate and palmitate in brain mince of normal and ketotic rats. Diabetes. 17: 90.

47. Ide, T., J. Steinke, and G. F. Cahill, Jr. 1969. Metabolic interactions of glucose, lactate and $\beta$-hydroxybutyrate in rat brain slices. Amer. J. Physiol. 217: 784.

48. Bates, M. W., H. A. Krebs, and D. H. Williamson. 1968. Turnover rates of ketone bodies in normal, starved and alloxan diabetic rats. Biochem. J. 110: 655 .

49. Havel, R. J., E. O. Balasse, H. E. Williams, J. P. Kane, and N. Segel. 1969. Splanchnic metabolism in Von Gierke's disease (glycogenosis type I). Trans. Ass. Amer. Physicians Philadelphia. 82: 305.

50. Hatef, Y., and T. Fakouhi. 1968. Control of $\beta$-hydroxybutyrate and acetoacetate oxidation by inorganic phosphate and adenosine $5^{\prime}$-diphosphate in heart mitochondria. Arch. Biochem. Biophy's. 125: 114.

51. Bieberdorf, F. A., S. S. Chernick, and R. O. Scow. 1970. Effect of insulin and acute diabetes on plasma FFA and ketone bodies in the fasting rat. J. Clin. Invest. 49: 1685 . 